Discussion Paper Series A No.694

\title{
Baumol versus Engel: \\ Accounting for 100 years (1885-1985) \\ of Structural Transformation in Japan
}

\author{
Kyoji Fukao \\ (Institute of Economic Research, \\ Hitotsubashi University) \\ and \\ Saumik Paul \\ (Osaka University and IZA)
}

May 2019

Institute of Economic Research

Hitotsubashi University

Kunitachi, Tokyo, 186-8603 Japan 


\title{
Baumol versus Engel:
}

\section{Accounting for 100 years (1885-1985) of Structural Transformation in Japan}

\author{
Kyoji Fukao $^{1}$ and Saumik Paul ${ }^{2}$
}

\begin{abstract}
This paper examines the drivers of the long-run structural transformation in Japan. We use a dynamic input-output framework that decomposes the reallocation of the total output across sectors into two components: the Engel effect (demand side) and the Baumol effect (supply side). To perform this task, we employ 13 seven-sector input-output tables spanning 100 years (1885 to 1985). The results show that the Engel effect was the key explanatory factor in more than $60 \%$ of the sector-period cases in the pre-WWII period, while the Baumol effect drove structural transformation in more than $75 \%$ of such cases in the post-WWII period. Detailed decomposition results suggest that in most of the sectors (agriculture, commerce and services, food, textiles and transport, communication and utilities), changes in private consumption were the dominant force behind the demand-side explanations. The Engel effect was found to be the strongest in the commerce and services sector, which contributed to the rapid growth of GDP in Japan throughout the 20th century.
\end{abstract}

Keywords: long-run structural transformation; the Engel effect; Baumol's cost disease effect; sectoral productivity growth

JEL Classifications: O40, O10

${ }^{1}$ Professor, Institute of Economic Research, Hitotsubashi University, Japan

${ }^{2}$ Researcher, Osaka University and IZA, email paulsaumik@gmail.com 


\section{Introduction}

"The principal virtue of the method of interindustry analysis is to show explicitly the interdependence of growth rates in different sectors of the economy"

Over the past two centuries, many industrialized countries have experienced dramatic changes in the sectoral composition of output and employment. The study of changing patterns of economic development, initiated by Simon Kuznets ${ }^{1}$ in the 1950s, has led to the identification of these long-run trends. The pattern of structural transformation, depicted for most of the developed countries, entails a steady fall in the primary sector, a steady increase in the tertiary sector, and a hump shape in the secondary sector. The theories advanced to explain the process of structural transformation can be broadly classified under two categories: the demand-side explanation, driven by the generalization of Engel's law, and the supply-side explanation, following the differences in the rate of productivity across sectors, also known as "Baumol's cost disease effect” (Baumol 1967). The goal of this paper is to account for the contribution of each of these drivers of structural transformation in Japan over a period of 100 years, from 1885 to 1985. A small literature devoted to this topic (Fourastie 1952; Grilliches 1992; Dennis and Iscan 2009) predominantly uses the theory-based growth accounting frameworks. We, instead, apply a dynamic input-output approach (Leontief 1951; Chenery, Shishido, and Watanabe 1962) to decompose the reallocation of total output across sectors. Due to the unavailability of historical input-output tables (in regular intervals) over a long period of time, this comprehensive approach has received limited attention. We overcome this constraint to a large extent by using 13 sevensector $^{2}$ input-output (IO) tables available between 1885 and 1985 (Shintani 1988).

We apply the Chenery, Shishido, and Watanabe (1962) framework to examine changes in the composition of sectoral output shares in Japan over a period of 100 years (1885-1985). During this period, the value-added share of the primary sector dropped from $60 \%$ to less than $1 \%$, whereas that of the tertiary sector rose from $27 \%$ to nearly $60 \%{ }^{3}$. To measure the sectoral imbalance in output growth, Chenery, Shishido, and Watanabe (1962) used an inter-industry model to explain deviations from proportional growth in output in each of the seven sectors and

\footnotetext{
${ }^{1}$ Kuznets (1955), Clark (1957), Chenery (1960) and Syrquin (1988) are among the early studies on this topic.

2 These sectors are: (1) agriculture, forestry, and fishing; 2) commerce and services; (3) construction; (4) food; (5) mining and manufacturing; (6) textiles; and (7) transport, communication, and utilities.

${ }^{3}$ Appendix 1 shows the sectoral value-added trends adapted from Fukao and Paul (2017).
} 
decomposed the deviation in sectoral output into four factors: (1) changes in the composition of domestic demand; (2) changes in the volume of exports; (3) changes in the volume of imports; and (4) changes in technology and organization. They considered the deviation from proportional expansion in the first three factors as autonomous changes, and the remaining variation as being due to the fourth component. Analyzing the process of industrialization and economic growth in Japan for the period from 1914 to 1954, they found that about 25\% of the changes in the sectoral output share are explained by changes in domestic aggregate demand while about $75 \%$ are traceable to changes in supply-side conditions (changes in technology and organization). Thus, the supply-side factors in their study played a much bigger role than the demand-side factors.

This paper extends the Chenery, Shishido, and Watanabe (1962) framework in several ways. First, we employ 13 input-output (IO) tables with seven broad sectors ${ }^{4}$ for the period from 1885 to 1985 estimated by Shintani (1988). We use seven IO tables (every 10 years) in the prewar era from 1885 to 1935 and six IO tables (every 5 years) in the postwar era from 1955 to 1985. In contrast, Chenery, Shishido, and Watanabe (1962) had only one input-output table (1954) available to them. They estimated the changes in input coefficients between 1914 and 1954 by comparing the production level of the 1914 technology with that of 1954 . We overcome this data constraint in our paper. Second, we consider a decomposition using a chain-index formula (Dietzenbacher and Los 1998), which provides a good approximation to the average of the outcomes from all the decomposition techniques. We modify the Chenery, Shishido, and Watanabe (1962) framework ${ }^{5}$ by incorporating this technique and decompose the deviation in sectoral gross output into various factors. Third, we decompose the demand-side explanation into domestic consumption, private investment, government consumption, exports, and imports to gain further insight into the role of each of these factors as part of the demand-side explanation.

The results show that the growth rate of GDP more than doubled in the post-WWII era compared to the pre-WWII era. The real output growth was the highest in the commerce and services sector throughout the period under study, but there was also rapid growth of output in mining and manufacturing, especially in the second half of the 20th century. Sectoral output growth in mining and manufacturing; commerce and services; and transport, communications, and utilities outgrew the pace of growth in GDP in most of the periods. In the pre-WWII era, the Engel effect played the key role in explaining the gap from proportional growth in output. This is opposite to the findings of Chenery, Shishido, and Watanabe (1962) for the period from 1914 to 1954. However, in the second half of the $20^{\text {th }}$ century, the Baumol effect became the key driver of structural transformation. Dennis and Iskan (2009) found similar results for the US. Their study

\footnotetext{
${ }^{4}$ These sectors are: (1) agriculture, forestry, and fishing; 2) commerce and services; (3) construction; (4) food; (5) mining and manufacturing; (6) textiles; (7) transport, communication, and utilities.

${ }^{5}$ Consider a standard Leontief model as $\boldsymbol{x}=\mathbf{A} \boldsymbol{x}+\boldsymbol{f}$, where $\boldsymbol{x}$ denotes the vector of sectoral outputs, A the matrix of input coefficients, and $\mathbf{f}$ the vector of final demands. The solution for the Leontief model is given by $\boldsymbol{x}=(\mathrm{I}-\mathrm{A})^{-1} \boldsymbol{f}$. Expressing $L=(I-A)^{-1}$, Chenery, Shishido, and Watanabe (1962) decomposed changes in output $x$ between period $\mathrm{o}$ and 1 using $\Delta \mathbf{x}=\Delta \mathbf{L} \boldsymbol{f}_{1}+\mathbf{L}_{0} \Delta \boldsymbol{f}$.
} 
showed that the Engel effect accounted for almost all labor reallocation until the 1950s, after which the Baumol effect became the main force. Detailed decomposition results show that in most of the sectors (agriculture; commerce and services; food; textiles; and transport, communication, and utilities) changes in private consumption were the dominant force behind the demand-side explanations. The Engel effect was the strongest in the commerce and services sector.

This paper mainly contributes to the literature on the contributions of key drivers of structural transformation over a long period of time. Economic historians (North 1966; Crafts 1980; Sokoloff 1986; Williamson 1986) have long recognized the importance of studies in sectoral reallocation of resources in understanding the long-term process of industrialization and economic growth. In a recent analysis, Herrendorf, Valentinyi, and Rogerson (2014) voiced similar concerns by highlighting the usefulness of documenting the historical process of structural transformation along with development and growth. Examining the process of structural transformation between 1800 and 2000, Dennis and Iscan (2009) found that the Engel effect dominated until the 1950s, after which the Baumol effect explains most of the changes in sectoral allocation of employment. Crafts (1980), in another study, found support for the role of the Engel effect for British industrialization. In a recent study, Iscan (2010) found that the Engel effect and the Baumol effect together explain about two thirds of the reallocation of labor from other sectors into services in the US during the $20^{\text {th }}$ century. Difficulties in putting together long time series data remained the main obstacle, which we overcome to a large extent with the help of novel input-output tables available for the period from 1885 to 1985.

The rest of the paper is organized as follows. In Section 2, we discuss the mechanisms of the Engel effect and the Baumol effect using a simple theoretical framework. Section 3 begins with a description of the Chenery, Shishido, and Watanabe (1962) framework, then provides some stylized facts on the stages of economic growth in Japan between 1885 and 1985, and then explains the empirical findings on the Baumol and Engel effects. We also discuss the outcomes of a more detailed decomposition of the demand-side explanation in Section 3. Section 4 concludes.

\section{Mechanisms of the Baumol effect and the Engel effect in a simple framework}

Over the past few decades, many theories have been developed in analyzing the process of structural transformation ${ }^{6}$. The theoretical models typically assume nonhomothetic preferences that generate low-income elasticity of demand for agricultural products and high-income elasticity of demand for nonagricultural products (Kongsamut, Rebelo and Xie 2001; Dennis

\footnotetext{
${ }^{6}$ See a recent comprehensive survey by Herrendorf, Valentinyi and Rogerson (2014).
} 
and Iscan 2009). With an increase in per capita income, nonhomothetic preferences predict a rise in the demand for manufacturing products or services resulting in reallocation of resources from agriculture to services. On the other hand, the theoretical models assume gross complementarity in the consumption preference for goods from different sectors to account for Baumol's cost disease effect (Ngai and Pissarides 2007). A difference in the level of productivity between sectors triggers a relocation of resources from a high-productivity sector to a low-productivity sector. This makes the sectoral outputs grow in tandem following the complementary preference in consumption. In this section, we use a theoretical model to discuss the mechanisms of the Baumol effect and the Engel effect. We do not claim any original contribution to the theory and keep the model simple.

Consider a three-sector model comprising agriculture (A), manufacturing (M), and services (S). We later discuss a generalization of the model outcomes to a seven-sector model. Assume that capital plays no role, and the output in each of these sectors is produced using labor and technology in a closed-economy environment ${ }^{7}$. The model solves a static resource allocation problem in each period.

\subsection{Utility maximization for a representative household}

An infinitely lived representative household maximizes utility from the consumption of products from agriculture $\left(C_{A}\right)$, manufacturing $\left(C_{M}\right)$, and services $\left(C_{S}\right)$, and in turn supplies labor to produce output in each of these sectors. Population is normalized to 1 and there is no population growth. A nonhomothetic preference in demand for agricultural goods implies that the representative household consumes agricultural products only up to a subsistence level $\left(\overline{C_{A}}\right)$, i.e., when $C_{A}<\overline{C_{A}}$, and cares more for the consumption of nonagricultural products (Kongsamut, Rebelo and Xie, 1997; Gollin 2007) when $C_{A}>\overline{C_{A}}$. This is driven by the lower-income elasticity of demand for agricultural products. The representative household

maximizes $U=\left\{\begin{array}{c}\overline{C_{A}} \text { if } C_{A}<\overline{C_{A}} \\ \overline{C_{A}}+\left(\emptyset_{M} \frac{1}{\sigma} C_{M}^{\frac{\sigma-1}{\sigma}}+\emptyset_{S} \frac{1}{\sigma} C_{S}^{\frac{\sigma-1}{\sigma}}\right)^{\frac{\sigma}{\sigma-1}} \text { if } C_{A}>\overline{C_{A}}\end{array}\right.$

subject to $p_{A} \overline{C_{A}}+p_{M} C_{M}+p_{S} C_{S}=w$.

$\emptyset_{M}$ and $\emptyset_{S}$ indicate how consumption expenditure is allocated between manufacturing and services; $p_{A}, p_{M}$, and $p_{S}$ represent prices for products in agricultural, manufacturing, and services, respectively; $\sigma$ represents a constant elasticity of substitution between manufacturing

\footnotetext{
${ }^{7}$ Our empirical analysis also digresses from the theoretical model to some extent.
} 
products and services reflecting preferences of the representative household for the consumption of products from these sectors. The preferences over the consumption of manufacturing goods and services are complementary if $\sigma<1$ and show substitutability when $\sigma>1 ; w$ is the wage that the representative household earns in exchange for its labor. Since labor moves across sectors, we do not allow $w$ to vary across sectors.

The first-order conditions, after some algebraic calculations from Equations (1.1) and (1.2), produce the price ratios as a function of consumption levels and the expenditure share parameters. This shows the conditions under which the utility from the consumption of manufacturing goods and services is maximized, given the prices for goods from each sector.

$$
\left(\frac{p_{M}}{p_{S}}\right)^{\sigma}=\frac{\emptyset_{M} C_{S}}{\emptyset_{S} C_{M}}
$$

\subsection{Technology and profit maximization for firms}

Production in each sector is a linear function of labor, as shown in Equation (1.4). $\beta_{k}$ is the total factor productivity in sector $k$, which is the technology that a representative firm in sector $k$ uses to produce $Y_{k}$ from employing $L_{k}$.

$$
Y_{k}=\beta_{k} L_{k}
$$

The representative firm in sector $k$ maximizes $\pi=p_{k} Y_{k}-w L_{k}$, and the first-order conditions for profit maximization produce price ratio as a function of technological parameters (1.5). Due to a linear production function, price becomes an inverse of the technology parameter, which implies that price goes down as a firm becomes more productive.

$$
\frac{p_{M}}{p_{S}}=\frac{\beta_{S}}{\beta_{M}}
$$

\subsection{Market clearing conditions and structural transformation}

Goods markets clear in each sector with $Y_{A}=\overline{C_{A}}, Y_{M}=C_{M}$ and $Y_{S}=C_{S}$. And the factor market clears when $L_{A}+L_{M}+L_{S}=1$. Combining Equations 1.3, 1.5, and the market clearing conditions, we get

$$
\left(\frac{\beta_{S}}{\beta_{M}}\right)^{\sigma}=\frac{\emptyset_{M} Y_{S}}{\emptyset_{S} Y_{M}} .
$$


The market clearing conditions in the agriculture sector give $L_{A}=\frac{\overline{C_{A}}}{\beta_{A}}$. Putting back the sectoral production functions in Equation 1.6, and after simple algebraic calculations, we get an expression for the employment in manufacturing sector, as follows:

$$
L_{M}=\frac{\emptyset_{M} \beta_{M}{ }^{\sigma-1}\left(1-\frac{\overline{C_{A}}}{\beta_{A}}\right)}{\emptyset_{M} \beta_{M}{ }^{\sigma-1}+\emptyset_{S} \beta_{S}{ }^{\sigma-1}} .
$$

We can use Equation 1.7 to explain the mechanisms of the Engel and the Baumol effect. Due to a lower income elasticity of demand for agricultural than for nonagricultural products, an increase in the income level lowers the demand for the subsistence level of agricultural consumption $\left(\overline{C_{A}}\right)$. This produces an upward thrust in the numerator of the expression for $L_{M}$, contributing to an increase in the employment level in the manufacturing sector due to the Engel effect. On the other hand, a higher level of productivity in the agricultural sector increases $\beta_{A}$, which produces a similar upward thrust in manufacturing employment but through a different channel. The labor moves from a more productive agriculture sector to a less productive manufacturing sector and maintains the parity in sectoral output following the complementarity in the preference over agricultural and manufacturing products. Equation 1.7 also captures the Baumol effect through productivity gain in services (an increase in $\beta_{S}$ ). An increase in $\beta_{S}$ leads to a higher $L_{M}$ since $\sigma<$ 1 due to complementarity between the demand for manufacturing products and services.

The expression for the level of employment in manufacturing in a three-sector model can be extended to a seven-sector model. Let us denote the seven sectors from the input-output tables as agriculture (A); commerce and services (S); construction (Co); food (F); mining and manufacturing $(\mathrm{M})$; textiles $(\mathrm{T})$; and transport, communication, and utilities (U). Assuming a nonhomothetic preference for demand in agricultural goods, we can rewrite Equation 1.7 for employment in the mining and manufacturing (M) sector as:

$$
L_{M}=\frac{\emptyset_{M} \beta_{M}{ }^{\sigma-1}\left(1-\frac{\overline{C_{A}}}{\beta_{A}}\right)}{\emptyset_{M} \beta_{M}{ }^{\sigma-1}+\emptyset_{S} \beta_{S}{ }^{\sigma-1}+\emptyset_{C o} \beta_{C o}{ }^{\sigma-1}+\emptyset_{T}{\beta_{T}}^{\sigma-1}+\emptyset_{F}{\beta_{F}}^{\sigma-1}+\emptyset_{U}{\beta_{U}}^{\sigma-1}}
$$

The denominator of Equation 1.8 shows the employment effect of productivity differences across all the nonagricultural sectors. The general equilibrium model discussed in this section assumes simultaneous clearance of both the goods market and the factor market. However, our empirical analysis based on a dynamic input-output model considers only the goods market. In addition, in an input-output framework the technological progress and the capital-labor substitution are indistinguishable from the changes in the inverse of the Leontief matrix, and they are lumped together into the supply-side explanation of the resource allocation across sectors. Nonetheless, 
we hope that the discussion of the Baumol effect and the Engel effect in a simple framework provides a good foundation to understand the empirical analysis in the following section.

\section{Input-output framework and the empirical outcomes}

"Input-output analysis is one of the major contributions to economics in the 20th century that accomplished the mutual support from theory, data and application"

- W. J. Baumol

We organize the description of empirical results in the following manner. We begin with a brief introduction of an extended version of the Chenery, Shishido, and Watanabe (1962) framework, which is followed by an overview of the growth in national and sectoral output from 1885 to 1985. We then discuss the gap between national output and sectoral output growth, and the role of the demand and supply side in the deviation in output from proportional growth. Finally, we provide a more disaggregated analysis of the role of the demand-side explanatory factors.

\subsection{An extension of the Chenery, Shishido, and Watanabe (1962) framework}

In this section we discuss the multisectoral input-output framework proposed by Chenery, Shishido, and Watanabe (1962), and offer some modifications to their methodology that we apply to our data. Consider a standard Leontief model with seven sectors (since the historical input-output tables we use in this paper contain only seven sectors):

$$
\text { (1) } x=A x+f
$$

$\boldsymbol{x}$ denotes a vector $(7 \times 1)$ of sectoral output, $\boldsymbol{f}$ is a vector $(7 \times 1)$ of aggregate domestic demand including net exports, and $A$ is a Leontief input-output matrix $(7 \times 7)$. A solution to this Leontief model is given by:

$$
\text { (2) } \boldsymbol{x}=(1-A)^{-1} \boldsymbol{f} \text {. }
$$

We are primarily interested in identifying the factors driving the growth in output (changes in $\boldsymbol{x}$ ). A number of techniques can be applied to decompose Equation 2. We consider an average of the polar forms of decomposition (Dietzenbacher and Los 1998), which provides a good approximation to the average of the outcomes from all the decomposition techniques. Following this method, $\Delta \boldsymbol{x}$ between time 0 and 1 can be decomposed as: 
(3) $\Delta x=\frac{1}{2}\left(\left(1-A_{0}\right)^{-1}+\left(1-A_{1}\right)^{-1}\right) \Delta \boldsymbol{f}+\frac{1}{2}\left(\boldsymbol{f}_{\mathbf{0}}+\boldsymbol{f}_{\mathbf{1}}\right) \Delta\left[(1-A)^{-1}\right]$.

To measure sectoral imbalance in output growth, Chenery, Shishido, and Watanabe (1962) used sectoral output growth proportional to the growth in domestic demand as a benchmark and decomposed the deviation in sectoral gross output resulting from it into various factors. Equation (4) presents a similar decomposition technique with aggregate domestic demand consisting of five categories: consumption, investment, government, export, and import.

$$
\begin{aligned}
& \boldsymbol{x}_{\mathbf{1}}-\lambda \boldsymbol{x}_{\mathbf{0}}=\left(I-A_{1}\right)^{-1}(\delta \boldsymbol{c}+\delta \boldsymbol{i}+\delta \boldsymbol{g}+\delta \boldsymbol{e}-\delta \boldsymbol{m})+ \\
& \quad\left[\left(I-A_{1}\right)^{-1}-\left(I-A_{0}\right)^{-1}\right] \lambda\left(\boldsymbol{c}_{\mathbf{0}}+\boldsymbol{i}_{\mathbf{0}}+\boldsymbol{g}_{\mathbf{0}}+\boldsymbol{e}_{\mathbf{0}}-\boldsymbol{m}_{\mathbf{0}}\right),
\end{aligned}
$$

where

$\boldsymbol{x}_{\mathbf{1}}=$ production in period 1

$\boldsymbol{c}_{\mathbf{1}}=$ domestic consumption demand in period 1

$\boldsymbol{i}_{\mathbf{1}}=$ private investment demand in period 1

$\boldsymbol{g}_{\mathbf{1}}=$ government expenditure in period 1

$\boldsymbol{e}_{\mathbf{1}}=$ export in period 1

$\boldsymbol{m}_{\mathbf{1}}=$ import in period 1

$A_{1}=$ Leontief matrix in period 1

$\lambda=1+$ growth rate of total domestic demand

$\delta c=c_{1}-\lambda c_{0}$

Taking an average of the polar forms of decomposition, we rewrite Equation (4) as:

$$
\boldsymbol{x}_{1}-\lambda \boldsymbol{x}_{\mathbf{0}}=\frac{1}{2}\left(\left(1-A_{0}\right)^{-1}+\left(1-A_{1}\right)^{-1}\right) \delta \boldsymbol{f}+\frac{1}{2}\left(\lambda \boldsymbol{f}_{\mathbf{0}}+\boldsymbol{f}_{\mathbf{1}}\right)\left[\left(I-A_{1}\right)^{-1}-\left(I-A_{0}\right)^{-1}\right]
$$

or

(5)' $x_{1}-\lambda x_{0}=$ Demand + Supply

where

$\delta \boldsymbol{f}=\delta \boldsymbol{c}+\delta \boldsymbol{i}+\delta \boldsymbol{g}+\delta \boldsymbol{e}-\delta \boldsymbol{m}$

$f_{0}=c_{0}+i_{0}+g_{0}+e_{0}-m_{0}$

$f_{1}=c_{1}+i_{1}+g_{1}+e_{1}-m_{1}$.

The first term on the right-hand side of Equation (5)' constitutes the demand-side effects and the second term the supply-side effects. Adding and subtracting $x_{0}$ on the left-hand side of Equation (5)' and simple algebraic manipulation give us:

$$
\underbrace{\boldsymbol{x}_{\mathbf{1}}-\boldsymbol{x}_{\mathbf{0}}}_{\begin{array}{c}
\text { Change } \\
\text { in sectoral } \\
\text { output }
\end{array}}=\underbrace{\text { Demand }}_{\begin{array}{c}
\text { Deviation in output } \\
\text { due to demand-side } \\
\text { factors }
\end{array}}+\underbrace{\text { Supply }}_{\begin{array}{c}
\text { Deviation in output } \\
\text { due to supply-side } \\
\text { factors }
\end{array}}+\underbrace{\boldsymbol{x}_{\mathbf{0}}(\lambda-1)}_{\begin{array}{c}
\text { Proportional growth } \\
\text { effect }
\end{array}}
$$


Equation (6) decomposes changes in sectoral output into (1) deviation in output from proportional growth driven by demand-side factors, (2) deviation in output from proportional growth driven by supply-side factors, and (3) proportional growth effect.

\subsection{Sectoral growth in gross output, domestic demand, and trade}

Table 1 shows the annual average growth rate of gross domestic product (gross domestic demand) for both the pre-WWII (every 10-year interval) and the post-WWII (every 5-year interval) periods. The GDP index in the right column (Table 1) suggests that the growth rate of domestic demand more than doubled in the post-WWII era compared to the pre-WWII era ${ }^{8}$. Domestic demand rose sharply in the period from 1885 to 1895. Between 1874 and 1890, the share of manufacturing activities increased substantially in all prefectures. The expansion of the manufacturing sector during this period was mainly driven by the expansion of traditional manufacturing activities such as food processing, wood products, and labor-intensive textile production, among others (Fukao and Paul 2017. During the period of the postwar growth miracle from 1955 to 1970, Japan's aggregate productivity rose remarkably. The growth in the demand for domestic products was the highest between 1965 and 1970. However, the periods since the early 1970s show a marked slowdown in Japan’s GDP growth.

[Table 1 is about here]

Figure 1 shows sector dynamics in terms of real output (left panel) and domestic demand (right panel) for the period from 1885 to 1985 . We first summarize the key features of the gross real output (depicted in log values) trends for seven sectors. Commerce and services remained the leading sector in terms of the volume of real output throughout the period. The importance of mining and manufacturing grew rapidly in the post-WWII era, and almost caught up with the output level of commerce and services. Gross output in the construction and food industries also surged after 1955 whereas agriculture and textiles saw a decline. After the abolition of strict regulations on international trade in 1954, Japan enjoyed a comparative advantage in silk products and suffered from a disadvantage in cotton products. Consequently, prefectures that specialized in cotton products - such as Aichi and Osaka - suffered (Fukao and Paul 2017). This explains why textiles had the smallest share of total gross output since 1955. Sectoral trends of gross real domestic demand closely resembled that of gross real output. One notable exception is

\footnotetext{
${ }^{8}$ The growth rates in the post-WWII periods are averaged over 5 years whereas the same for the pre-WWII periods are recoded for a 10-year interval.
} 
that the growth in the real domestic demand was much slower than the real output growth in mining and manufacturing after WWII. This is partly because the demand for mining and manufacturing products as inputs also increased during the same period, replacing more traditional sources of inputs mostly coming from agriculture.

[Figure 1 is about here]

The sectoral composition of Japan's exports and imports of goods dramatically changed between the pre-WWII and the post-WWII era (Figure 2). Agricultural and textile products dominated Japan's exports at the beginning of the $20^{\text {th }}$ century; however, by 1938 the rest of the sectors had surpassed the level of agricultural exports. The export demand for textile products, on the other hand, saw a less dramatic decline. In the second half of the $20^{\text {th }}$ century, mining and manufacturing and other service sectors clearly became the main sources of Japanese exports to the world. On the other hand, there was a steady growth of agricultural imports throughout this period. Manufacturing, food, and commercial products were the three other major import sectors for Japan, especially in the post-WWII era. Over time, the volume of total trade (exports + imports) in manufacturing and mining outpaced that in other sectors, which also contributed to the high growth in Japan during the 1960s.

[Figure 2 is about here]

\subsection{Output gap and deviation in output from proportional growth}

In Section 2, we derived a formula that decomposes changes in sectoral output between time periods 0 and $1\left(x_{1}-x_{0}\right)$ into (1) deviation in output from proportional growth $\left(x_{1}-\lambda x_{0}\right)$ and (2) proportional growth effect $\left(x_{0} \lambda-x_{0}\right) ; \lambda$ denotes the growth rate of gross domestic demand + 1. The deviation in output from proportional growth is further decomposed into the demand-side and the supply-side explanations, the results of which we explain in the next section. For a sector, if the deviation in output from proportional growth is positive (greater than zero), then it implies that that sector is growing at a rate higher than the growth rate of gross domestic product. The top panel of Figure 3 compares the actual output growth (black bars) with deviation in output to proportional growth (gray bars) for five time intervals spanning 1885 to 1935. For sectors like agriculture, and commerce and services, output grew in most of the pre-WWII periods at a rate slower than the growth rate of GDP. For construction and food, the results are 
mixed. However, in most of the periods, sectoral output in mining and manufacturing; textiles; and transport, communications, and utilities outgrew the rate of GDP growth.

[Figure 3 is about here]

The changes in the sectoral outcomes were more volatile across the post-WWII periods. The agriculture, textile, and food industries were the sectors that lagged behind in terms of output. The very high output growth in mining and manufacturing propelled the high-growth era (19551970). Between 1965 and 1970, the growth rate of output in mining and manufacturing was more than 65\%, which set the bar for GDP growth higher than the output growth in most of the other sectors. Commerce and services caught up fast, and from 1970 onwards the output growth in this sector has always been higher than the GDP growth rate. Based on the available findings, we assert that mining and manufacturing has been the main engine of the GDP growth throughout the period under consideration; commerce and services and transport, communication, and utilities joined hands in the later periods of the post-WWII era.

\subsection{The Engel (demand-side) versus the Baumol (supply-side) effects}

This section is central to the paper. We first discuss some stylized facts on how the Engel effect and the Baumol effect explain the deviation in sectoral output growth from the GDP growth rate. We have seven sectors and 11 periods (five from pre-WWII and six from post-WWII) in total, which gives us a total of 77 sector-time cases to study. In the pre-WWII era (Figure 4), in almost $66 \%$ of the 35 cases, the Engel effect plays a dominant role in explaining the gap between sectoral output growth and GDP growth, and in 60\% of the cases, both the Engel effect and the Baumol effect explain the changes in the sectoral output in the same direction. In the post-WWII era (Figure 5), the Baumol effect played a more dominant role than the Engel effect, and maintains this status for about $60 \%$ of the 42 cases. Another new development that we notice in the post-WWII periods is that in almost $75 \%$ of the cases, the Engel effect and the Baumol effect predict the sectoral output growth in the opposite direction to each other.

[Figure 4 is about here]

We now highlight the key outcomes of the Baumol effect and the Engel effect across sectors. The deviation in the output in the agricultural sector from the proportional growth in GDP is primarily driven by the Baumol effect. The outcomes for the rest of the sectors suggest mixed 
results. In the commerce and services sector, the Engel effect explained most of the output gap only after the high-growth (1955-1970) era. For sectors like food and textiles, the Engel effect dominated the pre-WWII periods whereas the output gap in the post-WWII period is mostly explained by the Baumol effect. In construction, transport, communication, and utilities, and mining and manufacturing, we do not find any discernible trend favoring either the demand-side or the supply-side drivers. Although the Baumol effect explains the gap in sectoral output in most of the cases in the post-WWII era, we found such evidence at the sectoral level only for agriculture, food, and textiles.

[Figure 5 is about here]

\subsection{Detailed decomposition of the Engel effect}

The Leontief input-output model allows us to disaggregate the demand-side effect further into the effects of private consumption, government consumption, investment, and exports net of imports. In Appendices 2 and 3, we indicate the contributions of each of these factors to the Engel effect. The empirical findings suggest that in most of the sectors (agriculture; commerce and services; food; textiles; and transport, communication, and utilities) changes in private consumption were the dominant force behind the demand-side explanations of the sectoral output gap in both the pre- and the post-WWII era. Changes in the level of investment explain the output gap in the construction sector, whereas government consumption played prominent roles as a driver of the demand-side explanations of the output gap in the commerce and services and mining and manufacturing sectors, especially in the pre-WWII periods. Net exports, on the other

hand, were the dominant factor in the demand-side explanation for the mining and manufacturing sector.

[Figure 6 is about here]

Figure 6 compares the changes in private and government consumption by sectors. In the preWWII periods, the Engel effect was prominent through government consumption (including military expenses) demand in manufacturing and mining, and in the commerce and services sector. Both private and government consumption of output in the commerce and services sector fell in the first half of the 20th century, which saw a dramatic revival in the second half. During the post-WWII periods, especially after the high-growth period, there was a steep increase in both private and government consumption. In 1985, the total consumption in commerce and 
services accounted for almost $50 \%$ of the GDP. The government consumption in the construction sector increased steadily from 2\% of the GDP in 1955 to about 10\% of the GDP in 1980 . Combining these findings with the steady growth of GDP until the 1980s, we conclude that the Engel effect was much more prominent in the commerce and services sector than in the rest of the sectors.

\section{Concluding remarks}

A structural approach allows us to study economic growth in a multisectoral framework where reallocation of resources from low-productivity to high-productivity sectors reduces bottlenecks to economic growth. An input-output model (Leontief 1951) provides a comprehensive way to study reallocation of resources across sectors. In this paper, we apply the Chenery, Shishido, and Watanabe (1962) framework to examine structural transformation in sectoral output shares in Japan over a period of 100 years, from 1885 to 1985. We modify their decomposition framework by incorporating a chain-index formula (Dietzenbacher and Los 1998), which provides a good approximation to the average of the outcomes from all the decomposition techniques. In addition, we employ 13 input-output (IO) tables with seven broad sectors for the period from 1885 to 1985 estimated by Shintani (1988).

The results show that during the post-WWII period, especially between 1955 and 1970, Japan's aggregate productivity rose remarkably. The growth in the demand for domestic products was the highest between 1965 and 1970. Commerce and services remained the leading sector in terms of real output; however, the importance of mining and manufacturing also grew rapidly in the second half of the 20th century. Sectoral output in mining and manufacturing; commerce and services; and transport, communications, and utilities led the GDP growth in most of the periods. In the pre-WWII era, the Engel effect played a dominant role in explaining the gap in sectoral output from proportional output growth. The Baumol effect became prominent in the second half of the 20th century and explained most of the changes in the composition of total output across sectors. Decomposition results at a more disaggregated level suggest that in most of the sectors (agriculture; commerce and services; food; textiles; and transport, communication, and utilities) changes in private consumption were the dominant force behind the demand-side explanations. The Engel effect was much more prominent in the commerce and services sector than in the rest of the sectors.

One drawback of the Chenery, Shishido, and Watanabe (1962) framework is that it considers the supply-side explanation as a residual term and the effect of technological change and the effect of input substitution are indistinguishable within the supply-side component. An extended model that addresses these concerns is the next step forward and we leave this task to future research. 


\section{References}

[1] Baumol, William J., 1967. Macroeconomics of unbalanced growth: the anatomy of urban crisis. American Economic Review 57, 415-426.

[2] Chenery, Hollis B. 1960. Patterns of industrial growth. American Economic Review 50, 624653.

[3] Chenery, Hollis B., Shuntaro Shishido and Tsunehiko Watanabe. 1962. The pattern of Japanese growth, 1914-1954, Econometrica 30, 1, 98-139.

[4] Clark, Colin, The Conditions of Economic Progress, 3rd ed., London: Macmillan, 1957.

[5] Crafts, Nicholas, 1980. Income elasticities of demand and the release of labor by agriculture during the British industrial revolution: a further reappraisal. Journal of European Economic History 9 153-163.

[6] Dennis, Benjamin N., and Talan B. I’scan, 2009. Engel versus Baumol: ac- counting for U.S. structural change using two centuries of data. Explorations in Economic History 46, 186202.

[7] Dietzenbacher, E. \& Los, B. (1998) Structural decomposition techniques: sense and sensitivity, Economic Systems Research, 10, pp. 307-323.

[8] Fourasti e, Jean, 1952. La Productivit'e. Presse Universitaires de France, Paris.

[9] Fukao, Kyoji and Saumik Paul (2017). "The Role of Structural Transformation in Regional Convergence in Japan: 1874-2008." Institute of Economic Research Discussion Paper No. 665. Tokyo: Institute of Economic Research.

[10] Griliches, Zvi, 1992. Introduction. In: Zvi Griliches (Ed.), Output Measure- ment in the Service Sectors. Studies in Income and Wealth 56. Univer- sity of Chicago Press for NBER, Chicago and London, pp. 1-22.

[11] Herrendorf, Berthold, Richard Rogerson, and Ákos Valentinyi (2014) "Growth and Structural Transformation,” Handbook of Economic Growth, vol. 2B. North Holland, Amsterdam and New York, 855-941 (Chapter 6).

[12] Iscan, Talan (2010) “How Much Can Engel’s Law and Baumol’s Disease Explain the Rise of Ser- vice Employment in the United States?,” The B.E. Journal of Macroeconomics: Vol. 10: Iss. 1 (Contributions), Article 26.

[13] Kongsamut, Piyabha, Sergio, Rebelo, Danyang, Xie, 2001. Beyond balanced growth. Review of Economic Studies 68, 869-882.

[14] Kuznets, Simon, Modern Economic Growth, New Haven: Yale University Press, 1966.

[15] Kuznets, Simon. 1955. “Economic Growth and Income Inequality,” American Economic Review 45(1): 1-28.

[16] Leontief W, 1951. The Structure of American Economy, 1919-1939, An empirical application of equilibrium analysis, New York, Oxford University Press.

[17] Ngai, Rachel L., Pissarides, Christopher A., 2007. Structural change in a multi-sector model of growth. American Economic Review 97, 429-443.

[18] North, Douglas, 1966. Industrialization in the United States. In: Habakkuk, H. J., Postan, H. (Eds.), The Cambridge Economic History of Europe, vol. 6. Cambridge University Press, Cambridge, pp. 673-705. pt. 2.

[19] Shintani, Masahiko (1988) "Structure Changes among Industries in Pre-war Japan: An Approach by Input-Output Analysis” Seinan Gakuin University.

[20] Sokoloff, Kenneth L. (1986) "Productivity Growth in Manufacturing during Early Industrialization: Evidence from the American Northeast, 1820 to 1860.” In Long-Term 
Factors in American Economic Growth, edited by Stanley L. Engerman and Robert E. Gallman, 679-729. University of Chicago Press.

[21] Syrquin, Moshe. 1988.Patterns of structural change, in Chenery, Hollis and Srinivasan, T.N. (Eds.), Handbook of Development Economics, vol. 1, Amsterdam and New York: North Holland, chapter 7, pp. 203-273.

[22] Williamson, Jeffrey G., 1986. Comment: Productivity growth in manufacturing during early industrialization: Evidence from the American Northeast, 1820-1860. In: Engerman, Stanley L., Gallman, Robert E. (Eds.), Long-Term Factors in American Economic Growth. Studies in Income and Wealth, vol. 51. University of Chicago Press for NBER, Chicago, pp. 729-733. 
Table 1. Growth rate of gross domestic demand (GDP)

\begin{tabular}{|c|c|c|}
\hline & Time period & GDP growth Index \\
\hline \multirow{4}{*}{$\begin{array}{c}\text { Pre-WWII } \\
\text { (every 10- }\end{array}$} & $1885-1895$ & 1.53 \\
\cline { 2 - 3 } year interval) & $1895-1905$ & 1.26 \\
\cline { 2 - 3 } & $1905-1915$ & 1.14 \\
\cline { 2 - 3 } & $1915-1925$ & 1.52 \\
\hline & $1925-1935$ & 1.33 \\
\hline \multirow{3}{*}{$\begin{array}{c}\text { Post-WWII } \\
\text { (every 5-year }\end{array}$} & $1955-1960$ & 1.35 \\
\cline { 2 - 3 } interval) & $1960-1965$ & 1.53 \\
\cline { 2 - 3 } & $1965-1970-1975$ & 1.74 \\
\cline { 2 - 3 } & $1975-1980$ & 1.27 \\
\cline { 2 - 3 } & $1980-1985$ & 1.17 \\
\hline
\end{tabular}

Source: Authors' calculations based on Shintani (1988) input-output tables. 
Figure 1. Sectoral real output and domestic demand, 1885-1985

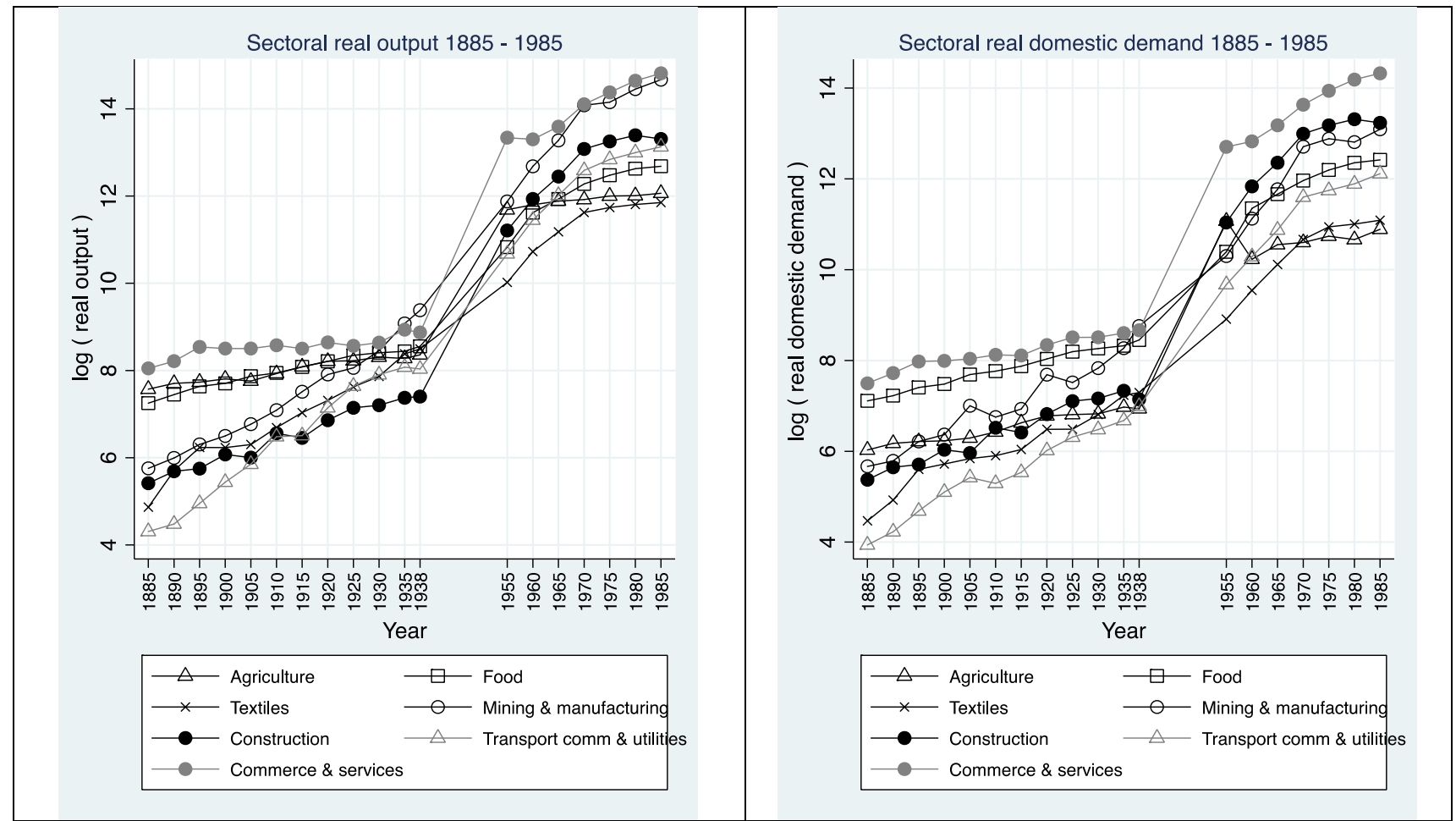

Source: Authors’ calculations based on Shintani (1988) input-output tables. 
Figure 2. Sectoral exports and imports, 1885-1985

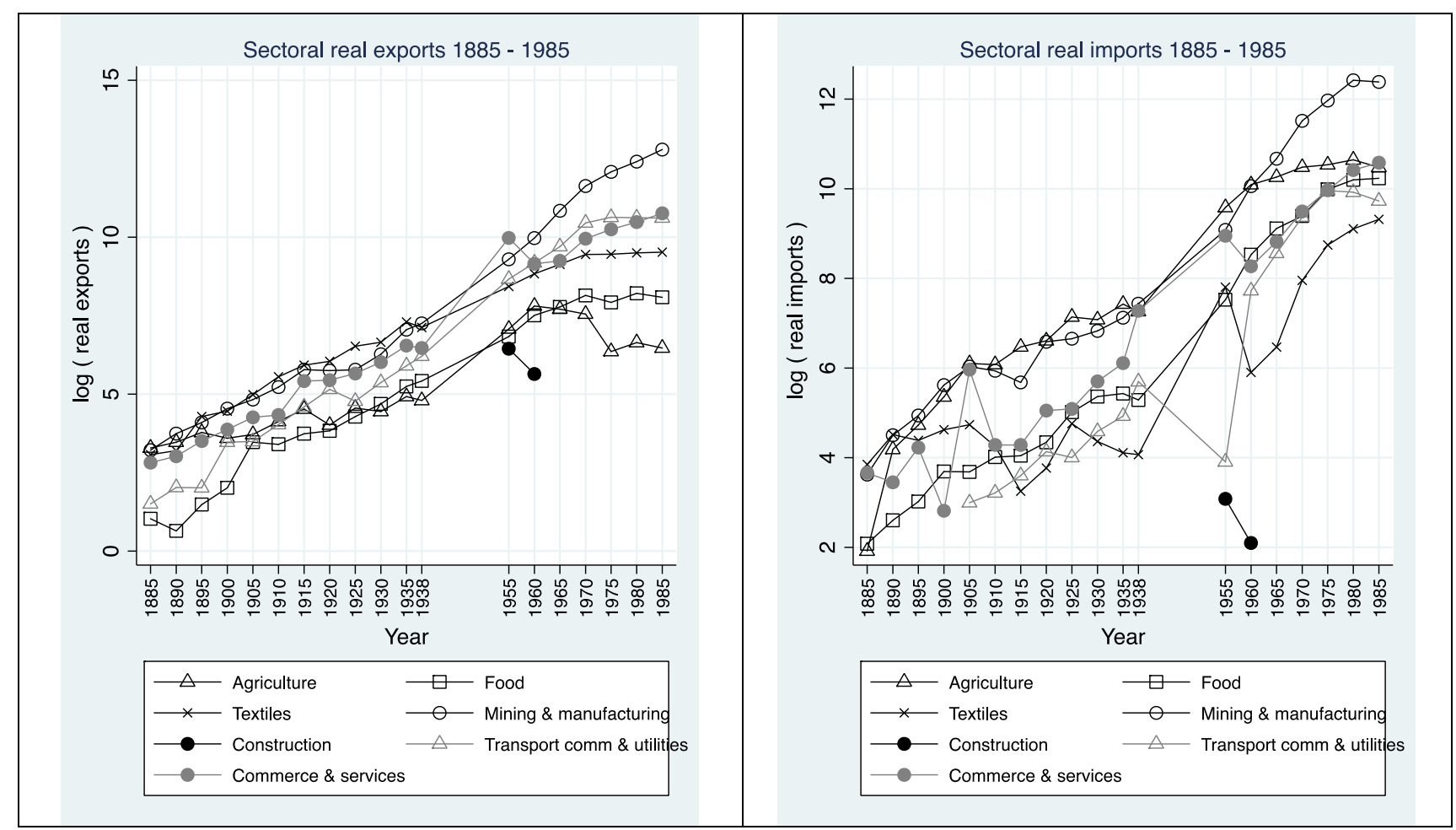

Source: Authors' calculations based on Shintani (1988) input-output tables. 
Figure 3. Output gap and deviation in output from proportional growth, 1885-1985

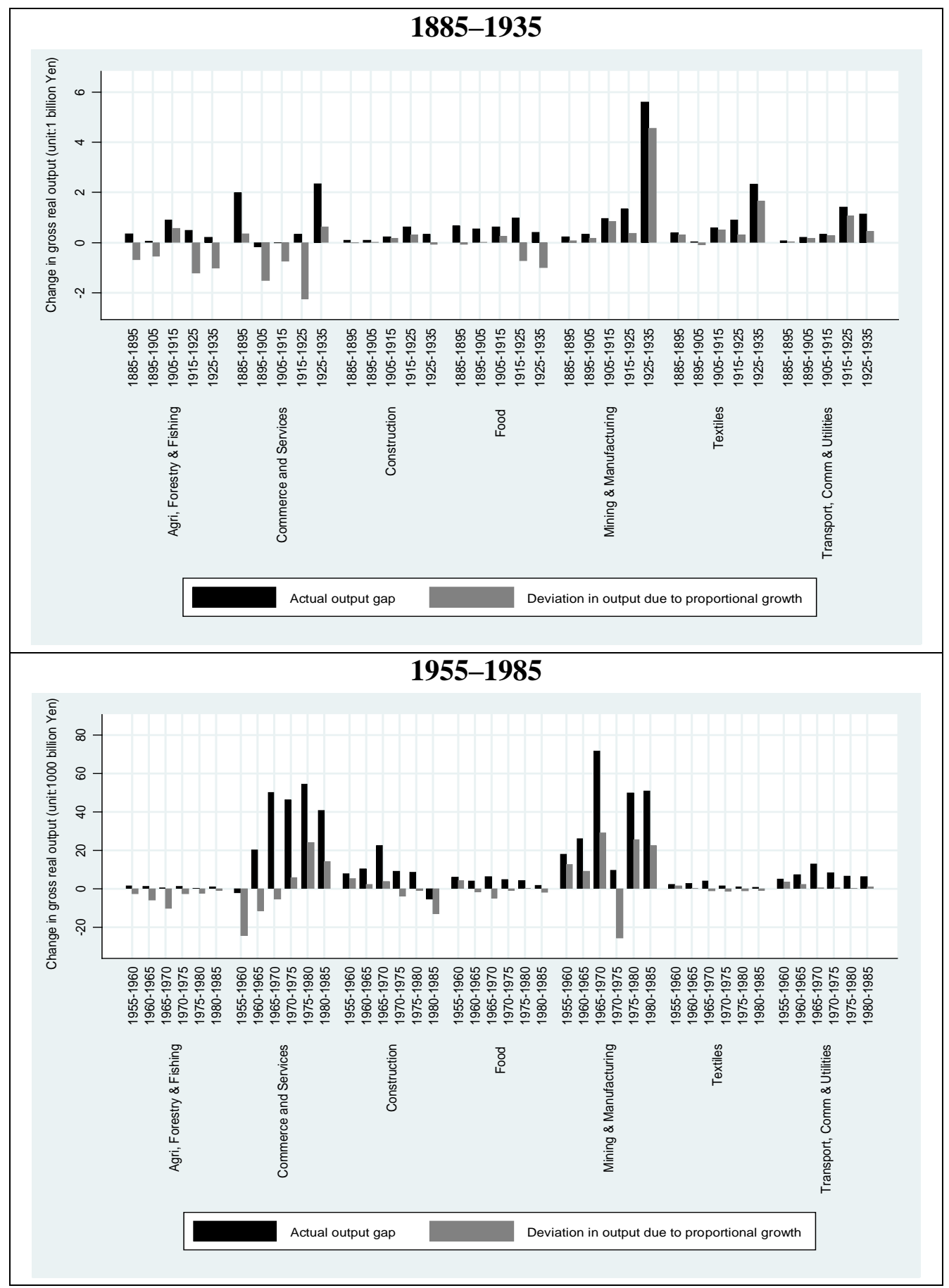

Source: Authors' calculations based on Shintani (1988) input-output tables.

Note: If deviation in output from proportional growth $\left(x_{1}-\lambda x_{0}\right)>0$, then a sector is growing at a rate higher than the growth rate of gross domestic product. Actual output gap is $\left(x_{1}-x_{0}\right)$. 
Figure 4. Engel (demand-side) versus Baumol (supply-side) effects, 1885-1935

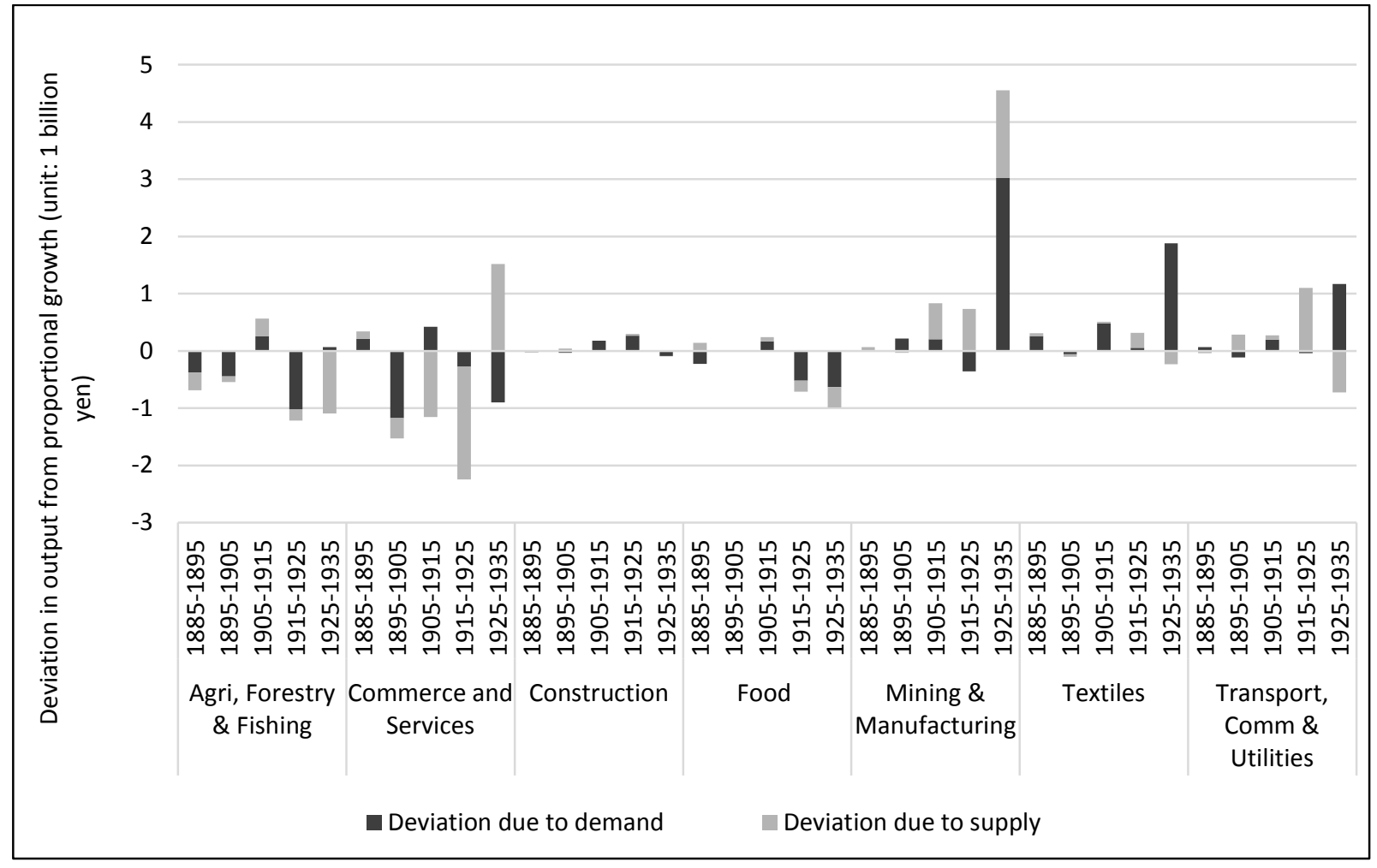

Source: Authors' calculations based on Shintani (1988) input-output tables.

Note: The demand-side and the supply-side effects add up to total deviation in output from proportional growth in GDP. 
Figure 5. Engel (demand-side) versus Baumol (supply-side) effects, 1955-1985

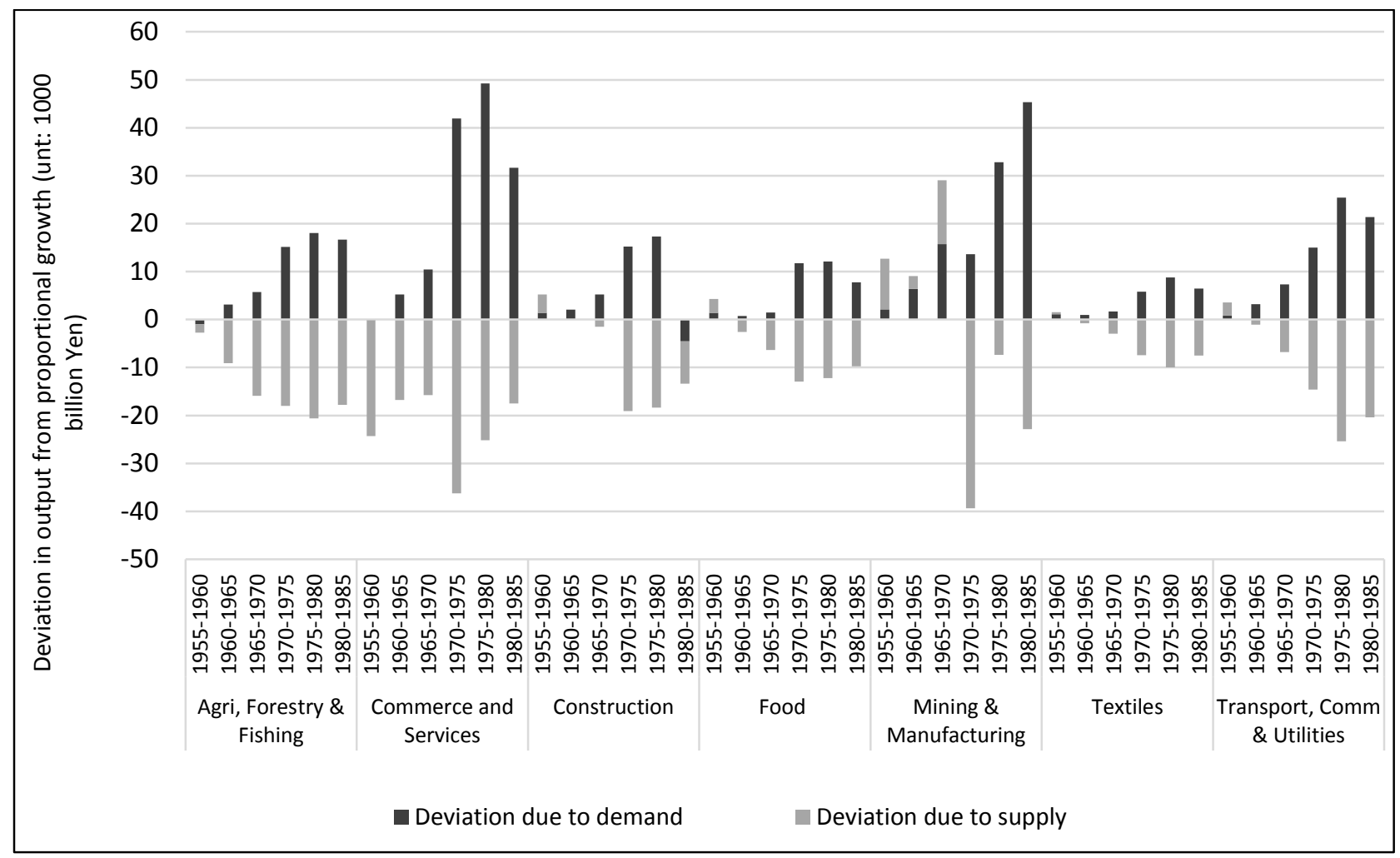

Source: Authors' calculations based on Shintani (1988) input-output tables.

Note: The demand-side and the supply-side effects add up to total deviation in output from proportional growth in GDP. 
Figure 6. The detailed Engel effects: private versus government consumption

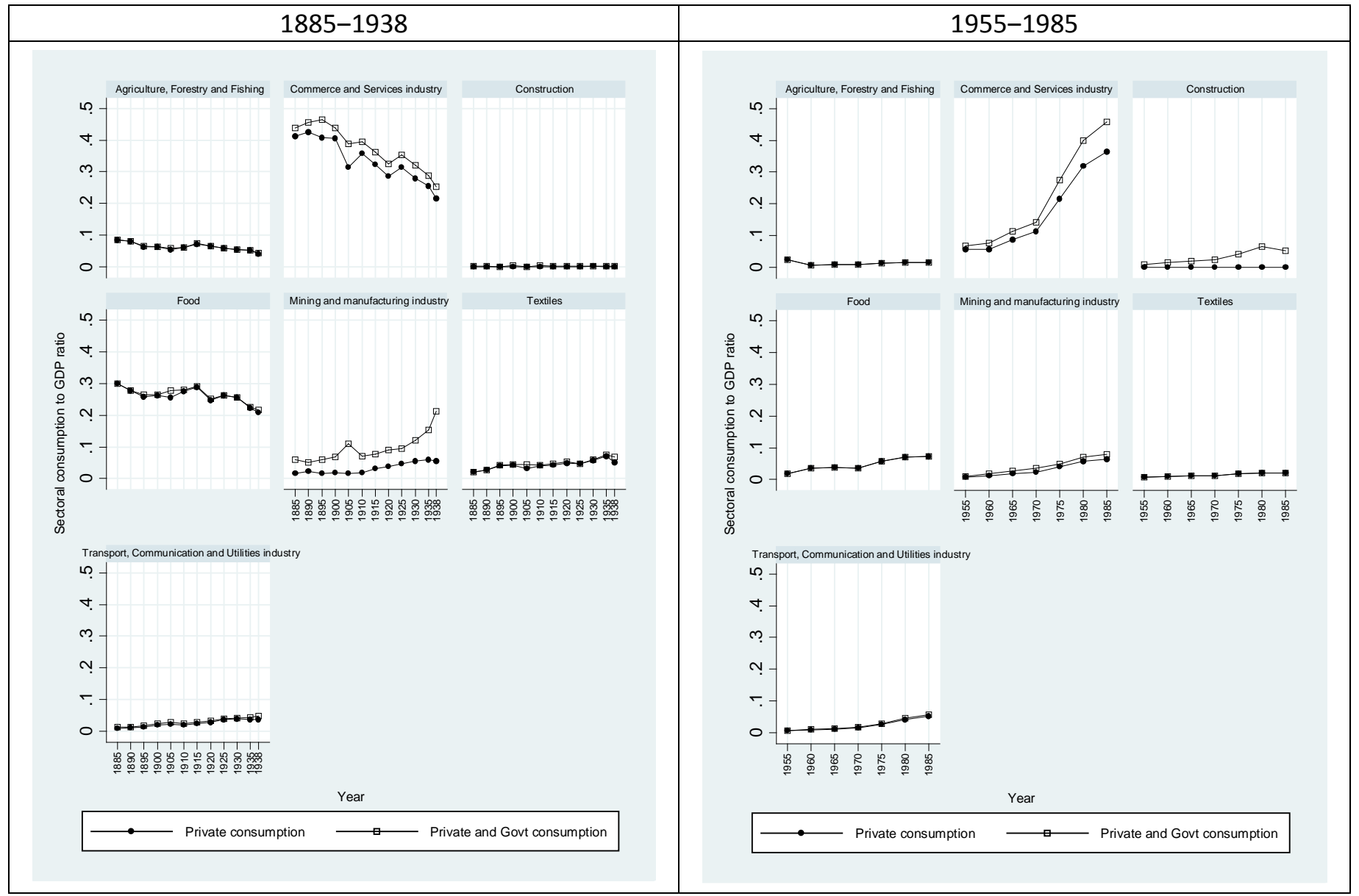

Source: Authors’ calculations based on Shintani (1988) input-output tables. 


\section{Appendix 1. Structural transformation in Japan}

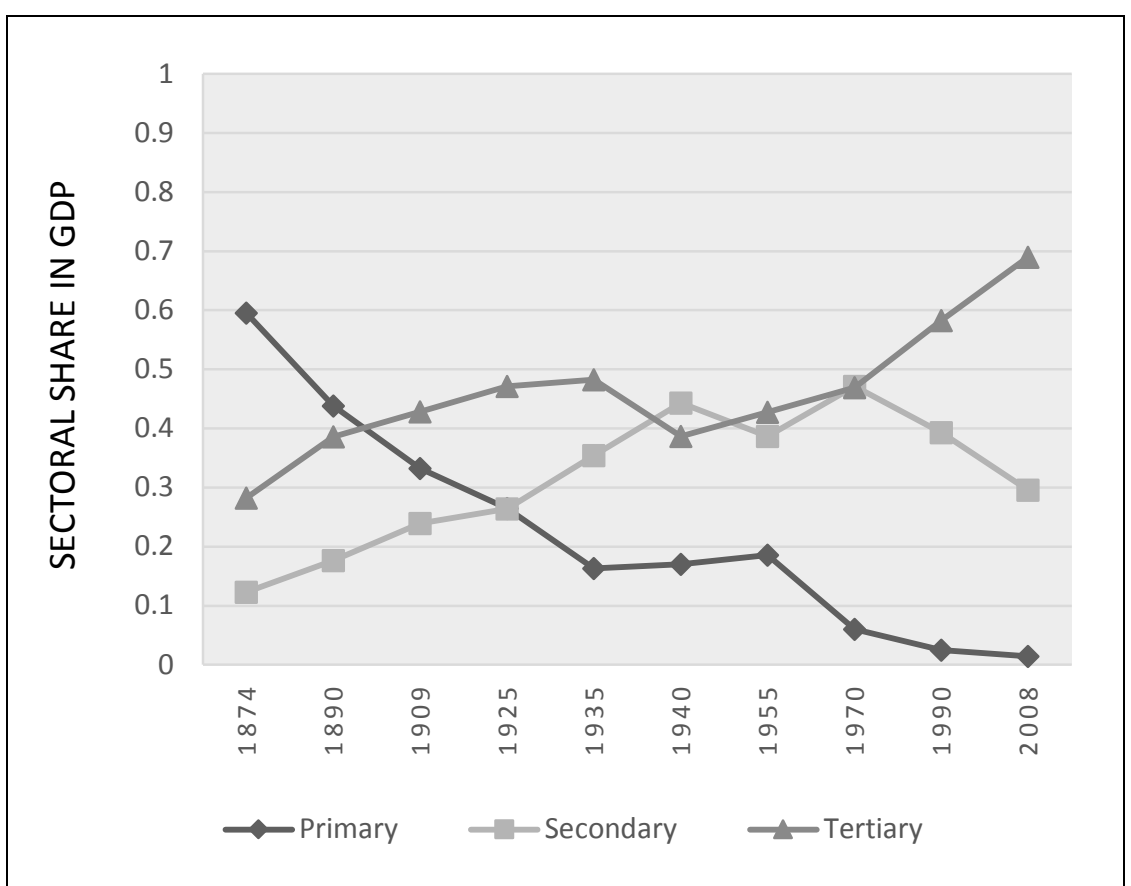

Source: Fukao and Paul (2017)

Note: Sectoral shares in GDP are calculated using real GDP in constant 1934-36 prices for 1874-1940 and constant 2000 prices for 1955-2008. 
Appendix 2. Detailed demand-side and supply-side effects, 1885-1935

\begin{tabular}{|c|c|c|c|c|c|c|}
\hline \multirow{2}{*}{ Sectors } & \multirow{2}{*}{ Demand and supply components } & \multicolumn{5}{|c|}{ Periods } \\
\hline & & 1885-1895 & 1895-1905 & 1905-1915 & 1915-1925 & 1925-1935 \\
\hline \multirow{6}{*}{$\begin{array}{l}\text { Agri, Forestry \& } \\
\text { Fishing }\end{array}$} & Private Consumption & 44.6 & 38.4 & 80.2 & 40.7 & 49.1 \\
\hline & Investment & 1.8 & 5.5 & 1.9 & 2.5 & -1.7 \\
\hline & Government consumption & -9.2 & -33.3 & -43.0 & 2.7 & -14.1 \\
\hline & Net exports & 17.4 & 70.9 & 5.5 & 37.6 & -39.7 \\
\hline & Aggregate demand & 54.6 & 81.5 & 44.6 & 83.6 & -6.5 \\
\hline & Aggregate supply & 45.4 & 18.5 & 55.4 & 16.4 & 106.5 \\
\hline \multirow{6}{*}{$\begin{array}{c}\text { Commerce and } \\
\text { Services }\end{array}$} & Private Consumption & -22.5 & 67.8 & -20.2 & 6.0 & -176.1 \\
\hline & Investment & 4.3 & -1.6 & -2.7 & -0.5 & 15.7 \\
\hline & Government consumption & 83.6 & -16.0 & 58.7 & 0.4 & -11.0 \\
\hline & Net exports & -3.1 & 26.8 & -93.5 & 6.4 & 26.9 \\
\hline & Aggregate demand & 62.4 & 77.0 & -57.7 & 12.3 & -144.6 \\
\hline & Aggregate supply & 37.6 & 23.0 & 157.7 & 87.7 & 244.6 \\
\hline \multirow{6}{*}{ Construction } & Private Consumption & 13.4 & -474.8 & 7.4 & -2.3 & 28.0 \\
\hline & Investment & 76.1 & 114.0 & 90.9 & 99.4 & 114.5 \\
\hline & Government consumption & -17.8 & 117.4 & -6.5 & -4.3 & -28.9 \\
\hline & Net exports & 2.8 & -202.7 & 13.4 & -3.5 & -15.7 \\
\hline & Aggregate demand & 74.5 & -446.1 & 105.1 & 89.3 & 97.9 \\
\hline & Aggregate supply & 25.5 & 546.1 & -5.1 & 10.7 & 2.1 \\
\hline \multirow{6}{*}{ Food } & Private Consumption & 343.4 & -5397.9 & 139.6 & 57.3 & 77.4 \\
\hline & Investment & -2.2 & 115.6 & 0.9 & -0.2 & -0.7 \\
\hline & Government consumption & -81.9 & 7079.5 & -92.4 & 4.4 & -2.2 \\
\hline & Net exports & 13.2 & -1356.1 & 21.6 & 11.5 & -10.8 \\
\hline & Aggregate demand & 272.4 & 441.1 & 69.6 & 73.0 & 63.7 \\
\hline & Aggregate supply & -172.4 & -341.1 & 30.4 & 27.0 & 36.3 \\
\hline \multirow{6}{*}{$\begin{array}{c}\text { Mining \& } \\
\text { Manufacturing }\end{array}$} & Private Consumption & -18.8 & -44.2 & 23.7 & 56.1 & 6.3 \\
\hline & Investment & 101.4 & 44.1 & 8.3 & 25.1 & 13.4 \\
\hline & Government consumption & 35.2 & 248.7 & -64.2 & 10.6 & 27.4 \\
\hline & Net exports & -103.1 & -129.6 & 56.3 & -187.5 & 19.3 \\
\hline & Aggregate demand & 14.7 & 119.0 & 24.2 & -95.8 & 66.4 \\
\hline & Aggregate supply & 85.3 & -19.0 & 75.8 & 195.8 & 33.6 \\
\hline \multirow{6}{*}{ Textiles } & Private Consumption & 43.9 & 205.8 & 29.9 & 15.9 & 42.5 \\
\hline & Investment & 1.9 & -5.8 & 0.7 & 1.4 & 0.9 \\
\hline & Government consumption & 26.4 & -141.4 & -26.2 & -9.8 & 7.1 \\
\hline & Net exports & 10.3 & 1.7 & 89.5 & 8.8 & 63.7 \\
\hline & Aggregate demand & 82.5 & 60.4 & 94.1 & 16.3 & 114.2 \\
\hline & Aggregate supply & 17.5 & 39.6 & 5.9 & 83.7 & -14.2 \\
\hline \multirow{6}{*}{$\begin{array}{c}\text { Transport, Comm } \\
\text { \& Utilities }\end{array}$} & Private Consumption & 46.9 & -82.1 & 34.6 & 15.2 & -19.8 \\
\hline & Investment & 17.3 & 5.0 & 4.7 & 2.8 & 49.8 \\
\hline & Government consumption & 194.4 & 56.7 & -77.0 & 0.2 & 104.2 \\
\hline & Net exports & -10.4 & -48.9 & 109.6 & -21.8 & 128.0 \\
\hline & Aggregate demand & 248.2 & -69.2 & 71.9 & -3.6 & 262.1 \\
\hline & Aggregate supply & -148.2 & 169.2 & 28.1 & 103.6 & -162.1 \\
\hline
\end{tabular}

Source: Authors' calculations based on Shintani (1988) input-output tables.

Note: Demand-side and supply-side contributions as percentages of the deviation in sectoral output from GDP growth. 
Appendix 3. Detailed demand-side and supply-side effects, 1955-1985

\begin{tabular}{|c|c|c|c|c|c|c|c|}
\hline \multirow{2}{*}{ Sectors } & \multirow{2}{*}{ Demand and supply components } & \multicolumn{6}{|c|}{ Periods } \\
\hline & & $1955-1960$ & 1960-1965 & $1965-1970$ & 1970-1975 & 1975-1980 & 1980-1985 \\
\hline \multirow{6}{*}{$\begin{array}{l}\text { Agri, Forestry } \\
\text { \& Fishing }\end{array}$} & Private Consumption & 23.9 & -24.7 & -10.4 & -468.9 & -531.4 & -472.3 \\
\hline & Investment & -13.6 & -4.4 & -25.2 & -12.0 & -99.8 & -290.0 \\
\hline & Government consumption & -8.9 & -4.4 & -6.1 & -57.4 & -98.2 & -118.2 \\
\hline & Net exports & 34.4 & -19.2 & -14.9 & -2.7 & 43.9 & -651.0 \\
\hline & Aggregate demand & 35.8 & -52.8 & -56.6 & -541.0 & -685.5 & -1531.5 \\
\hline & Aggregate supply & 64.2 & 152.8 & 156.6 & 641.0 & 785.5 & 1631.5 \\
\hline \multirow{6}{*}{$\begin{array}{c}\text { Commerce and } \\
\text { Services }\end{array}$} & Private Consumption & -0.9 & -37.1 & -116.6 & 572.1 & 160.9 & 130.6 \\
\hline & Investment & -2.2 & -2.5 & -54.1 & 19.1 & 13.9 & 19.1 \\
\hline & Government consumption & -3.6 & -7.2 & -21.9 & 155.7 & 36.6 & 38.2 \\
\hline & Net exports & 7.5 & 1.9 & -2.7 & -5.3 & -6.5 & 35.3 \\
\hline & Aggregate demand & 0.8 & -44.9 & -195.4 & 741.6 & 204.8 & 223.1 \\
\hline & Aggregate supply & 99.2 & 144.9 & 295.4 & -641.6 & -104.8 & -123.1 \\
\hline \multirow{6}{*}{ Construction } & Private Consumption & 0.6 & 14.2 & 11.2 & -52.2 & -226.0 & -8.6 \\
\hline & Investment & 20.8 & 50.1 & 98.7 & -212.8 & -750.2 & 19.6 \\
\hline & Government consumption & 10.4 & 31.8 & 29.9 & -125.2 & -658.2 & 27.8 \\
\hline & Net exports & -4.6 & -0.7 & 0.4 & 0.5 & 14.2 & -4.6 \\
\hline & Aggregate demand & 27.1 & 95.4 & 140.2 & -389.6 & -1620.3 & 34.2 \\
\hline & Aggregate supply & 72.9 & 4.6 & -40.2 & 489.6 & 1720.3 & 65.8 \\
\hline \multirow{6}{*}{ Food } & Private Consumption & 37.4 & -36.5 & -6.2 & -1004.9 & -9398.8 & -205.8 \\
\hline & Investment & 4.2 & -4.0 & -9.7 & 1.1 & -747.5 & -49.8 \\
\hline & Government consumption & 3.9 & -5.5 & -4.2 & -105.9 & -1236.8 & -42.6 \\
\hline & Net exports & -13.8 & 7.0 & -9.3 & 83.6 & 432.2 & -84.5 \\
\hline & Aggregate demand & 31.8 & -39.0 & -29.3 & -1026.0 & -10950.9 & -382.7 \\
\hline & Aggregate supply & 68.2 & 139.0 & 129.3 & 1126.0 & 11050.9 & 482.7 \\
\hline \multirow{6}{*}{$\begin{array}{c}\text { Mining \& } \\
\text { Manufacturing }\end{array}$} & Private Consumption & 4.7 & 28.1 & 10.7 & -50.0 & 70.0 & 33.9 \\
\hline & Investment & 17.0 & 9.5 & 37.4 & 3.5 & 60.7 & 40.7 \\
\hline & Government consumption & 6.1 & 8.3 & 6.9 & -4.2 & 20.5 & 10.3 \\
\hline & Net exports & -11.3 & 24.4 & -0.9 & -2.2 & -22.2 & 116.7 \\
\hline & Aggregate demand & 16.6 & 70.3 & 54.1 & -53.0 & 128.9 & 201.7 \\
\hline & Aggregate supply & 83.4 & 29.7 & 45.9 & 153.0 & -28.9 & -101.7 \\
\hline \multirow{6}{*}{ Textiles } & Private Consumption & 25.5 & 470.6 & -73.6 & -339.8 & -525.2 & -269.5 \\
\hline & Investment & 11.2 & 28.1 & -99.7 & -13.3 & -152.2 & -70.5 \\
\hline & Government consumption & 8.1 & 78.0 & -20.8 & -51.9 & -128.2 & -60.5 \\
\hline & Net exports & 28.6 & -36.3 & 66.3 & 58.3 & 91.8 & -241.5 \\
\hline & Aggregate demand & 73.4 & 540.4 & -127.9 & -346.6 & -713.7 & -642.0 \\
\hline & Aggregate supply & 26.6 & -440.4 & 227.9 & 446.6 & 813.7 & 742.0 \\
\hline \multirow{6}{*}{$\begin{array}{c}\text { Transport, } \\
\text { Comm \& } \\
\text { Utilities }\end{array}$} & Private Consumption & 12.8 & 85.3 & 496.7 & 3371.9 & 28588.3 & 1028.7 \\
\hline & Investment & 18.8 & 17.8 & 649.4 & 171.7 & 7617.7 & 301.0 \\
\hline & Government consumption & 11.5 & 22.2 & 152.8 & 603.9 & 6580.0 & 199.1 \\
\hline & Net exports & -20.2 & 23.2 & 70.9 & -242.3 & -3278.0 & 812.2 \\
\hline & Aggregate demand & 23.0 & 148.4 & 1369.9 & 3905.1 & 39508.1 & 2341.1 \\
\hline & Aggregate supply & 77.0 & -48.4 & -1269.9 & -3805.1 & -39408.1 & -2241.1 \\
\hline
\end{tabular}

Source: Authors' calculations based on Shintani (1988) input-output tables.

Note: Demand-side and supply-side contributions as percentages of the deviation in sectoral output from GDP growth. 